that the liat 4 er becomes more effective in catalyzing the formation of Ado- $3^{\prime}, 5^{\prime}-P$.

This study was supported in part by a grant (H-5835) from the United States Public Healuh Service and was conducted during the time in which one of us (E. B.) was a recipient of a I.ederle Medical Faculty Award.

Department of Biochemistry. Hoziard University College of Medicine. Wilitiak A. ANidirson, Jr. Washington, D.C. (U.S.A.) Eartene Brow:

1 E. W. Suthercand. T. W. Rall axt T. Menon, J. Biol. Chom., 237 (1962) 220.

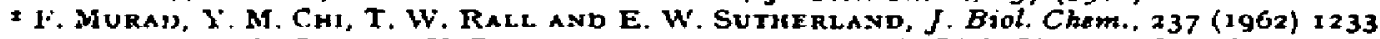

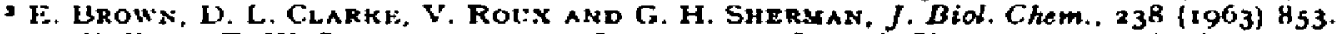

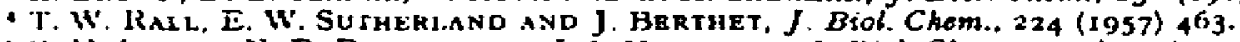

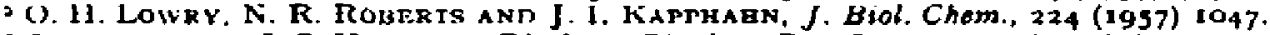

- J. ORloff and J.S. Handlki, Biochem. Biophys. Res. Commion., 5 (r961) 63.

Received November z6th, $x 962$

Biochim. Biophys. Ada, 67 (1963) $674-676$

sc. 11043

\title{
Biotin- and adenosine triphosphatedependent activation of propionyl apocarboxylase
}

As reported previously, $[2-14 \mathrm{C}]$ biotin is oxidized to labeled $\mathrm{CO}_{2}$ and acetoacetate by cell-frec preparations of a soil bacterium grown on biotin as sole carbon source ${ }^{1,2}$. A biotin-activating enzyme obtained from the bacterial extracts appears to catalyze the following, reactions, as shown by the ATP-dependent conversion of biotin to hiotin hydroxamate, stimulated by CoA, and by a [ ${ }^{\mathrm{O} P}$ ]pyrophosphate-ATP exchange which is inhibited by Co.A:

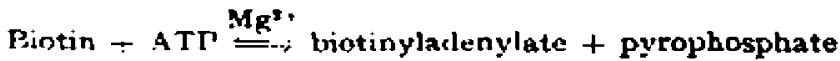

$$
\begin{aligned}
& \text { Biotiryladenylate }+\operatorname{CoA} \rightleftharpoons \text { biotinyl-COA }+ \text { AMP }
\end{aligned}
$$

The present report is concerned with the possibility that carboxyl activation occurs as a step in the incorporation of biotin into proteins as well as in biotin oxidation. In agreement with the fundings of Kosow AND LANEs, we have shown that activation of the apoenzyme of propionyl-CoA carboxylase (EC 6.4.1.3) and the bindirg of $\left.\right|^{14} \mathrm{C}$, biotin to proteins in cell-free extracts of biotin-deficient liver are deperident upon the presence of ATP (Table I) . The carboxylase activity (as measured by ${ }^{1+} \mathrm{LO} \mathrm{O}_{t}$ fixation) when biotin is omitted is a measure of the residual holocarboxylase present in the biotin-tiencient extracts. Since the omission of ATP $x$ glitathione givis a similar valuc, it may the concluded that the effect of bictin in activating the apicarboxylase is almost entirely ATP-dependent and also requires the presence of glitathione, presunably to stabilize the apoenzyme. The overall apoenzyme-activatin 5 reaction, which is stimulated by the presence of $\mathbf{M g}^{2+}$ but not consistently by CoA, may be formulated as follows: 


$$
\begin{aligned}
& \text { AT } P
\end{aligned}
$$

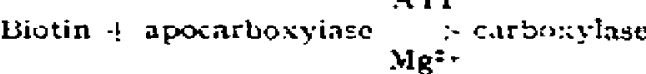

The requirements for binkling ${ }^{14} \mathrm{C}$. biotin to protein in the soluble system from: biotin-deficient rat liver are also shown in Table $\mathrm{I}$. The reaction is clearly ATP-and magnesium-dependent, whereas glutathione is not required.

\section{IA BEE}

REQUIKEMENTS FOR ACTIVATION OF APOFNZYME OF PROPIONYL-COA CAKBOXYIASE

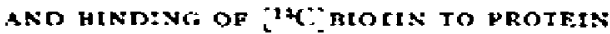

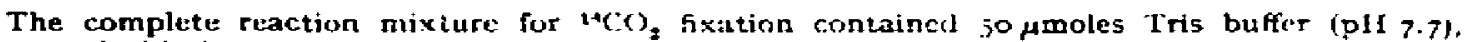
1 amole biotin. 5 amoles ATP. 5 /moles glitithiune. $2 /$ moles $\mathrm{MgCl}_{3}$ and o- $+5 \%$ ammonium sulfate fraction of biotin-rleficient rat liver (3.0 $\mathrm{mg}$ protein) in a tinal volume of $10 \mathrm{ml}$. After incubation for $3 \mathrm{~h}$ ac $37^{2}$ an jlipuot $(0.2 \mathrm{ml}$ ) was asiayal for propionyl-cok carboxylase with ${ }^{14} \mathrm{CO}$, according to the procedure of TiET2 ANO $0 \mathrm{CHOA}^{3}$. The: complete vHluc represents $0.38 / 4 \mathrm{~mole}$ CO, fixed per hour. The complete reaction mixture for lid biotin binding contained jo pmoles

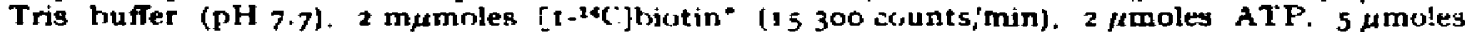

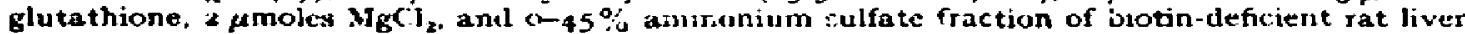
$\left(3.7 \mathrm{mg}\right.$ protein). Incubation, th at $37^{\circ}$. Proteins were then precipitated with trichlosacetic: acid. resuspended and washed thoroughly times with dilute trichloroscetic acid and assayer in byamine solution in a scintillation courter. Thic complete value represents o.ob mumule biotin txund

\begin{tabular}{|c|c|c|}
\hline System & 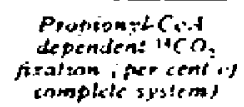 & 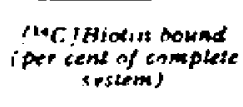 \\
\hline Complete & 100 & INO \\
\hline $\begin{array}{l}\text { No biotin } \\
\text { No ATT }\end{array}$ & 53 & \\
\hline $\begin{array}{l}\text { No glutatrione } \\
\text { No } \mathrm{JuCl}_{\mathrm{H}}\end{array}$ & 87 & 35 \\
\hline No enzyme & 2 & \\
\hline 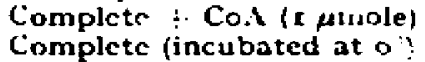 & 120 & 89 \\
\hline
\end{tabular}

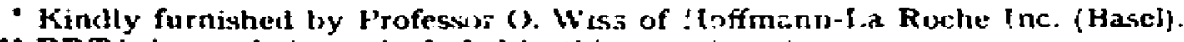

- EDTA (s amoleg) was includet in this experiment.

The complete enzyme system has been rex: $:+1$ into apuenzyme and apuenzymeactivating fractions, as indicated in recent preliminary 1 hrts from this lavoratoryt and by Kosow anis Lane.

We have recently found that liver of various species contains a biois: artivating enzyme similar to the bacterial enzyme already described. The enzyme, assayed $u_{:}$ the ATP-dependent formation of biotin hyd-mxamate in the presence of CoA and $\mathbf{M g}^{2+}$, has been purified about 20 -fold from pig-liver extracts. Such preparations, unlike the bacterial preparations, significantly stimulate propionyl-CoA carboxylase formation from the apoenzyme (Table II). Whether interfering enzyrsis are sent in the bacterial system is not yet clear. A rat-liver apocarboxylase prepara..... containing only traces of the biotin-activating enzymt was incubated in Expts. = and 2 with partially purified biotin-activating enzyme from pig liver and in Expts. 3 and 4 with an activating system from biotin-deficient rat liver. 


\section{TABLE II}

\section{KEQUUIRR: : ST OF TWO ENZYME FRACITONS IN ACTIVATION OF APOENZYME OF PROPIONYL-COA CARBOXYLAS̈E}

The reaction mixture for determining propioryl apocarboxylase activation was like that in Table 1 but with enzyme preparations as follows. Fat-liver apoonzyme preparation obtajned by $D E A E$ ccilulose rbromatograpby ( $1.0 \mathrm{mg}$ protein in Fxpt. 1) cr from an alumina $C_{y}$ gel supernatant fraction (:.2, 1.9, and $1.2 \mathrm{mg}$ protein in Expto, 2-4). Apocarboxylase-activating $9 y s t e r$ from pig liver (o.3 and $0.2 \mathrm{mg}$ protein in Exptg. I and 2) or from biotin-deficient rat liver (o.9 and $1.2 \mathrm{mg}$ protwin in Expts. 3 and 4 ). The valueg in parentheses represent experiments in which biotin was ornitted.

\begin{tabular}{|c|c|c|c|c|}
\hline Enirme trection rist & & Tolal coun & fited & \\
\hline & Expe. 2 & $E x p=$ & Exp: 3 & $\boldsymbol{F} \boldsymbol{x \boldsymbol { H }}$ \\
\hline $\begin{array}{l}\text { A pocarboxylase } \\
\text { Activating system } \\
\text { Apocarbuxylase activatuilg system }\end{array}$ & $\begin{array}{r}1730 \\
2960\end{array}$ & $\begin{array}{rr}820 & (430) \\
40 & (40) \\
1410 & (500)\end{array}$ & $\begin{array}{r}610 \\
359 \\
1462\end{array}$ & $\begin{aligned} 850 & (850) \\
640 & (470) \\
2300 & \end{aligned}$ \\
\hline Increase due to combining fractions & $71 \%$ & $64 \%(6 \%)$ & $51 \%$ & $54 \%$ \\
\hline
\end{tabular}

These experiments establish a requirement for at least two soiuble enzyme fractions an the biotin- and ATP-dependent formation of propionyl-CoA carboxylase from its apoenzyme: (a) the apoenzyme, in extracts of biotin-deficient liver, and (b) an apoenzyme-activating system present in both normal and biotin-deficient tissues. Although the results obtained indicate that a biotin-activating enzyme is present in the latter fraction, a conclusion as to the possible role of biotinyladenylate in apocarboxylase activation must await further enzyme purification.

This work was supported by a grant from the U.S. Fublic Health Srrvice (Grant No. A-4;(9)).

Departnient of biological Chemisiry.

Medical Schoal, Universiiy of Michigan.

Ann Arbor, Mich. (U.S.A.)
J. '.. FOOTE*

J. E. Christser**

M. J. COON

1 J. E. Chisistagr, J. L. Foutz and M. J. Coon, Federation Proc., 20 (196r) 271.

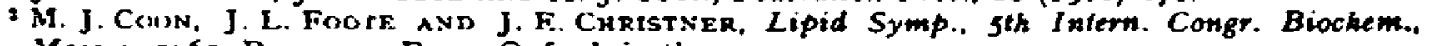
Moscow ${ }_{196}$. Pergamon Press, Oxford. in the piess.

- D. P. Kosow and M. D. Lane. Biochem. Biophys. Res. Commun. 5 (196I) $19 \mathrm{r}$.

- J. L. Focite, J. E. Chaistrie ano M. J. Coon. Federation Proc., 21 (1962) 239.

- A. Treti: and S. Ochó. J. Biol. Chem., 234 (1959) 1394.

- D. P. Kosow and M. D. IAave. Fedevation Proc.. 21 (1962) 286.

Received October 3otr. rg6z

- Pustiluctoral fellow oi tlus National Science Foundation.

- Prorlin'torel follnw of the National Science Foundation. 